\title{
Fertilizer improves seed and oil yield of safflower under tropical conditions
}

\author{
Marinez Carpiski Sampaio ${ }^{\mathrm{a}, *}$, Reginaldo Ferreira Santos ${ }^{\mathrm{a}}$, Doglas Bassegio ${ }^{\mathrm{b}}$, \\ Edmar Soares de Vasconselos ${ }^{\mathrm{c}}$, Marcelo de Almeida Silva ${ }^{\mathrm{b}}$, Deonir Secco ${ }^{\mathrm{a}}$, \\ Tiago Roque Benetoli da Silva ${ }^{\mathrm{d}}$ \\ a Universidade Estadual do Oeste do Paraná, UNIOESTE, Pós-graduação em Energia na Agricultura, CEP 85819-130, Bairro Faculdade, Cascavel, PR, Brazil \\ ${ }^{\mathrm{b}}$ Universidade Júlio de Mesquita Filho, UNESP, Departamento de Produção e Melhoramento Vegetal, UNESP, CEP 18603-970, Botucatu, SP, Brazil \\ c Universidade Estadual do Oeste do Paraná, UNIOESTE, Campus de Marechal Cândido Rondon - Centro de Ciências Agrárias, CEP 85960-000, Marechal \\ Cândido Rondon, PR, Brazil \\ ' Universidade Estadual de Maringá, UEM, Campus Avançado de Umuarama, Departamento de Ciências Agronômicas, CEP 87020-900, Maringá, PR, Brazil
}

\section{A R T I C L E I N F O}

\section{Article history:}

Received 11 May 2016

Received in revised form 4 August 2016

Accepted 17 September 2016

Available online 22 September 2016

\section{Keywords:}

Carthamus tinctorius

Oil content

Oil yield

Oilseed

\begin{abstract}
A B S T R A C T
Safflower (Carthamus tinctorius L.) has gained importance as an oilseed crop due to its hardiness and oil, which can be used in the production of biofuels. Studying proper crop management methods is highly important for the development of safflower in Brazil, since applying fertilizers correctly and using the appropriate time are efficient ways to achieve higher yield. Thus, the objective of this study was to evaluate safflower yield components, seed yield and oil content in two growing seasons. Two experiments under dryland conditions were conducted in 2014 in Cascavel, PR, Brazil. A randomised complete block design with three replications was used. Five rates of NPK fertilizer were used (0, 200, 400, 600 and $800 \mathrm{~kg} \mathrm{ha}^{-1}$ of $\mathrm{N}-\mathrm{P}_{2} \mathrm{O}_{5}-\mathrm{K}_{2} \mathrm{O}$ formula 4-14-8) in two growing seasons (autumn and winter). Even in a Rhodic Acrudox with high concentrations of $\mathrm{P}$ and $\mathrm{K}$, the application of NPK fertilizer in the furrow improved seed yield and oil yield in the autumnal growing season. Safflower seed yield averaged 2068 and $3820 \mathrm{~kg} \mathrm{ha}^{-1}$ in autumn and winter, respectively. The application of NPK fertilizer to safflower in the autumnal growing season significantly increased oil content (23.9\%). The linear plateau model predicted increased yield with NPK rates $<652 \mathrm{~kg}$ and $<610$ NPK ha ${ }^{-1}$, resulting in seed yield and oil yield of approximately $4374 \mathrm{~kg} \mathrm{ha}^{-1}$ and $1048 \mathrm{~kg} \mathrm{ha}^{-1}$, respectively. Safflower seems promising as an alternative oilseed crop for Southern Brazil when seeded in autumn with basic fertilization.
\end{abstract}

(c) 2016 Elsevier B.V. All rights reserved.

\section{Introduction}

Due to the global demand for bio-energy species, safflower (Carthamus tinctorius L.) stands out in Brazil as an alternative in the production of food and energy (Santos and Silva, 2015; Santos et al., 2015). Due to its hardiness and favorable agronomic characteristics, safflower can be an alternative for arid areas, since it can be used in crop rotation for being tolerant to drought and having a deep root system (Merrill et al., 2002; Lovelli et al., 2007; Hussain et al., 2015).

One of the most efficient ways for safflower to develop in tropical conditions with high efficiency is by applying fertilizers correctly. However, one needs to know the proper amount of fer-

\footnotetext{
* Corresponding author.

E-mail address: mari_marinez@hotmail.com (M.C. Sampaio).
}

tilizer to apply and also when and how to perform the application in a way that meets the growing needs of the environment. In tropical soils, farmers usually rely on the short-term positive effects of chemical fertilizers to maintain high crop yield.

In Brazil, safflower is an option for the second crop (off-season). Due to shortage of time and irregular rainfall, farmers prefer to use little or no fertilizer at sowing, which can hinder the performance of crops (Bicudo et al., 2009). Safflower has nutritional requirements that are similar to those of wheat, but it can access deeper layers of nutrients due to its root system (Haghighati, 2010). All nutrients are important for the crop, however, studies indicate that basic fertilization with nitrogen $(\mathrm{N})$ (Dordas and Sioulas, 2008; Yau and Ryan, 2010; El-Mohsen and Mahmoud, 2013), phosphorus (P) (Abbadi and Gerendas, 2011; Golzarfar et al., 2012) and potassium (K) (Hussien and Wuhaib, 2010; Palizdar et al., 2011; Abbasieh et al., 2013) has been highly efficient on safflower growth throughout the world. The effects of fertilization on safflower development 


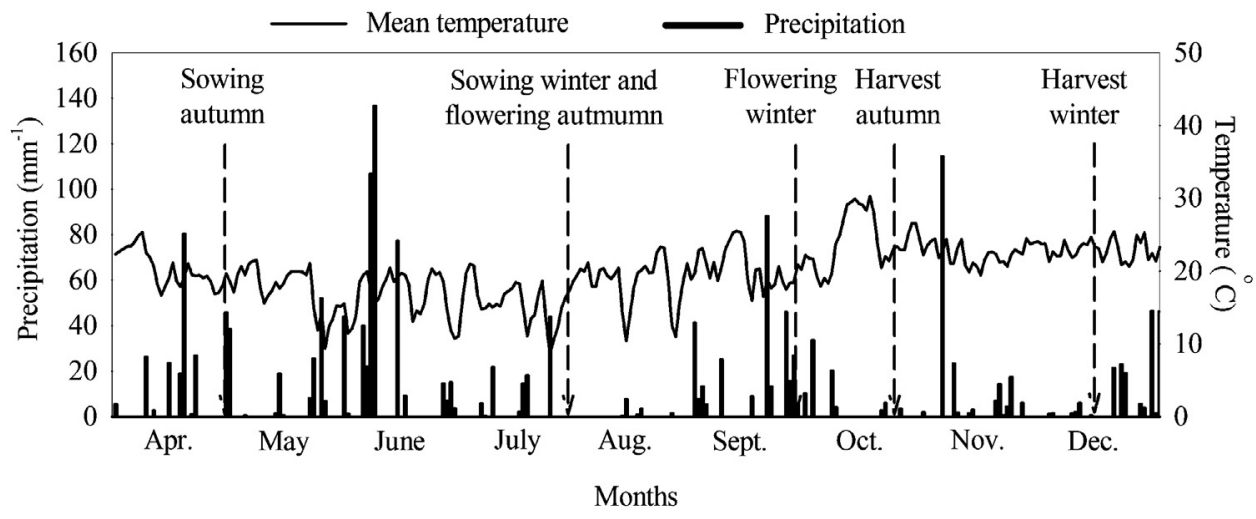

Fig. 1. Behavior of meteorological variables of precipitation and mean temperature during safflower cultivation seasons in Cascavel, PR, Brazil, in 2014.

Table 1

Soil chemical attributes $(0-2 \mathrm{dm})$ in two growing seasons.

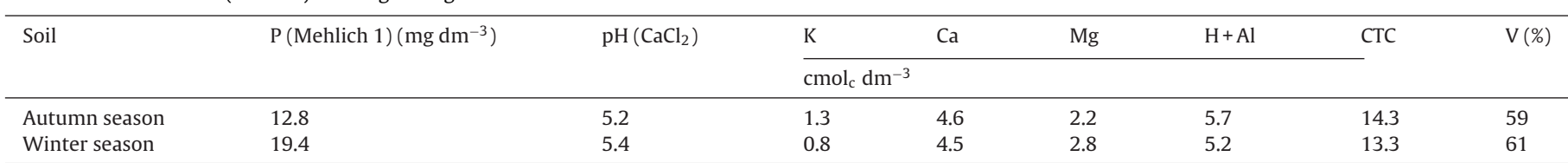

have not been extensively studied, especially in Brazil, and existing studies are limited to controlled conditions that do not focus on oil production (Bonfim-Silva et al., 2015; Anicésio et al., 2015).

In addition to fertilization, time of sowing and the period of nutrient uptake directly interfere in safflower crop productivity (Mündel, 2004), since the plants can complete their growth cycle before the beginning of the dry months due to increased metabolic activity and rapid growth, which can change their phenotype to escape drought conditions (Sherrard and Maherali, 2006).

Safflower yield and oil components may be affected by many factors, such as genotype, ecology, morphology, physiology and fertilization (Cosge et al., 2007). The time of sowing has great impact on safflower oil properties (Senkal et al., 2016).

Several studies report that sowing safflower in autumn may lead to a significant increase in seed yield (Koutroubas et al., 2004; Yau, 2007; Golzarfar et al., 2012). Thus, due to the low fertility of tropical soils, low volume of scientific information on the subject and the hypothesis that safflower response to basic fertilization is dependent on sowing seasons, the aim of this study was to evaluate the effects of different fertilizer rates on yield components, seed yield and safflower oil content in two growing seasons.

\section{Materials and methods}

\subsection{Location and climatic conditions}

Two experiments were conducted in 2014 in Cascavel, Paraná State, Brazil, whose geographic coordinates are $24^{\circ} 56^{\prime} 40^{\prime \prime} \mathrm{S}$ and $53^{\circ} 30^{\prime} 31^{\prime \prime} \mathrm{W}$ with an average altitude of $715 \mathrm{~m}$. The behavior of the meteorological variables of the experiment is shown in Fig. 1.

The soil of the experimental area was classified as Rhodic Acrudox (Soil Survey Staff, 2014). The experimental area had been managed in a no-tillage system for over 20 years, with corn or soybean crops in the summer and oats or wheat crops in the fall/winter seasons. Soil properties are presented in Table 1.

\subsection{Experimental set-up}

The first growing season started with sowing on April 30, 2014 (autumn), and the second one on July 30, 2014 (winter). In the first season, safflower was sown after soybean. Sowing in winter at low temperatures may cause negative effects on plant growth and on the seed filling stage.

The safflower genotype IAPAR was sown manually, leaving 10 plants per meter after thinning (222 thousand plants per ha).

\subsection{Treatments and experimental design}

A randomised complete block design with three replications was used. Each block was divided into five plots, to which five rates of $\mathrm{N}-\mathrm{P}_{2} \mathrm{O}_{5}-\mathrm{K}_{2} \mathrm{O}$ (4-14-8) fertilizer were applied $(0,200,400,600$ and $800 \mathrm{~kg} \mathrm{ha}^{-1}$ ). Each plot consisted of four rows measuring $4 \mathrm{~m}$ long, with spacing of $0.45 \mathrm{~m}$ between rows.

\subsection{Traits evaluated}

When the flowering stage reached $50 \%$, at 80 and 60 days after emergence in the autumn season and winter season, respectively, plant height was determined by measuring the distance between the soil level and the plant apex with a graduated tape. Six random plants were measured within each plot. The number of branches and capitula per plant was also determined when flowering reached $50 \%$ from six random plants from each plot. Stem diameter was also determined, by measuring the basal region of the stem with a digital caliper. The safflower plants were separated into stem, branches, roots and capitula in the flowering stage and dry matter was determined by drying at $65^{\circ} \mathrm{C}$ until constant weight was obtained.

Harvest took place after 160 and 140 days after emergence in the autumn and winter seasons, respectively, and seed yield was determined. Plants were collected from a linear meter of each plot and manual threshing and cleaning of the seeds were performed. Values were expressed in $\mathrm{kg} \mathrm{ha}^{-1}$. The 1000 -seed weight was determined by counting sub-samples of 100 seeds per plot. The samples were weighed on a precision scale to two decimal places. Moisture content was determined gravimetrically by drying a subsample for $24 \mathrm{~h}$ at $105^{\circ} \mathrm{C}$ and corrected to $12 \%$. The 1000 -seed weight was determined in accordance with the Rules for Seed Analysis (Brasil, 2009).

Oil content was determined by TD-NMR in an SLK-SG-200 spectrometer (Spin Lock Magnetic Resonance Solutions, Malagueño, 

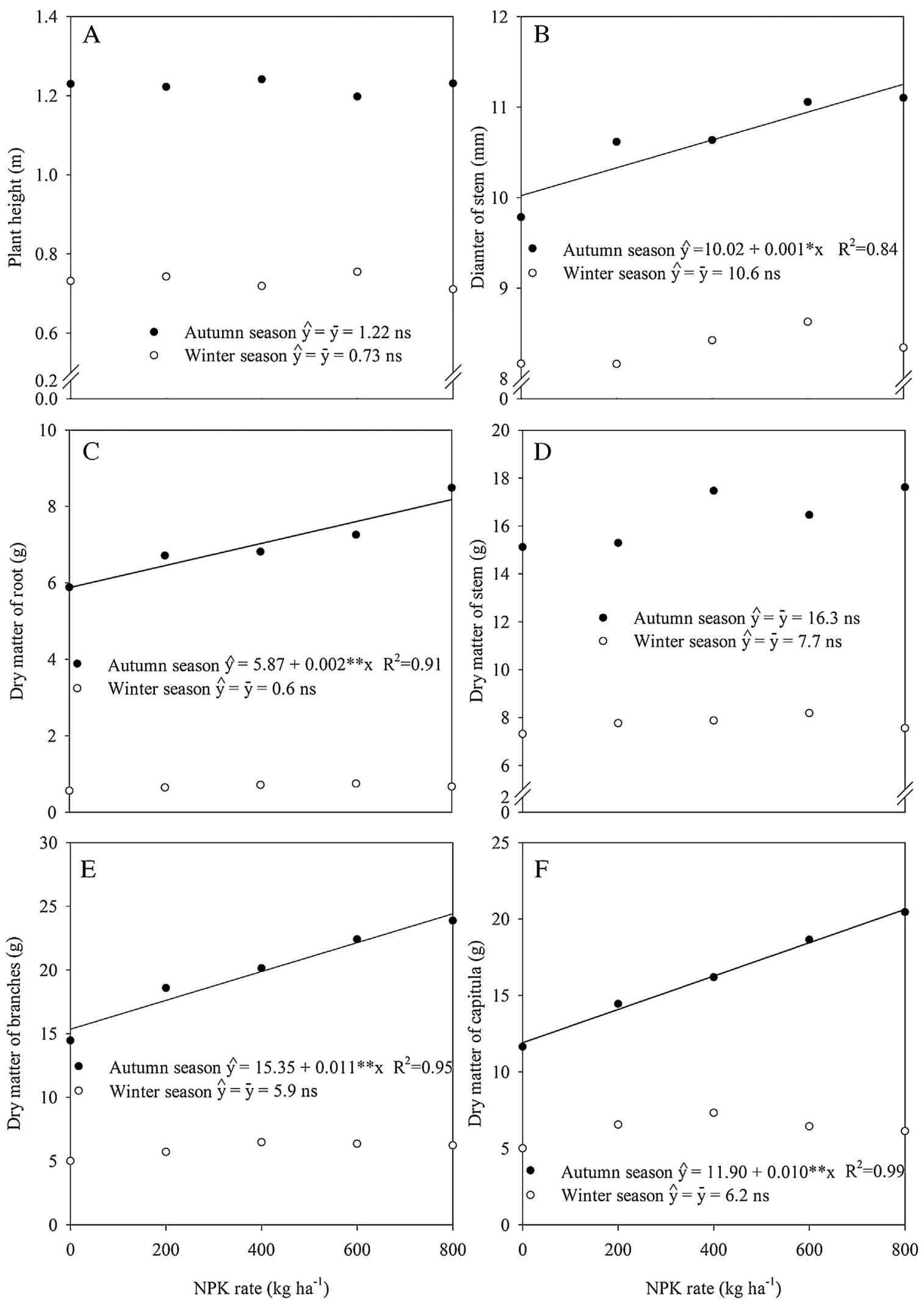

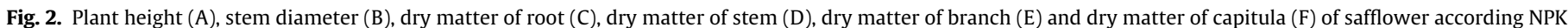
rates (4-14-8) in two growing seasons. ns: not significant. ${ }^{* *}$ Significant at $P \leq 0.01$ probability. ${ }^{*}$ Significant at $P \leq 0.05$ probability.

Córdoba, ARG) at $25^{\circ} \mathrm{C}$, equipped with a permanent magnet of $0.23 \mathrm{~T}(9 \mathrm{MHz}$ for $1 \mathrm{H})$ and a probe with $13 \mathrm{~mm} \times 30 \mathrm{~mm}$ useful area. Condor IDE software was used with CPMG pulse sequence and
Qdamper (Colnago et al., 2011). Results were expressed on a dry basis (\% DB). Oil yield $\left(\mathrm{kg} \mathrm{ha}^{-1}\right)$ was calculated as the product of oil content and seed yield. 
Tabela 2

Sources of variation, yield componentes, seed yield and oil yield of safflower.

\begin{tabular}{|c|c|c|c|c|c|c|c|c|c|c|c|c|}
\hline Sources of variation & $\mathrm{PH}$ & SD & DMR & DMS & NB & DMB & NC & DMC & SY & TSW & OIL & OY \\
\hline Winter & 1.22 & 10.6 & 7.0 & 16.3 & 6.4 & 19.8 & 12.5 & 16.2 & 3820 & 68.7 & 23.5 & 907 \\
\hline Autumn & 0.73 & 8.3 & 0.6 & 7.7 & 6.8 & 5.9 & 9.3 & 6.2 & 2068 & 48.4 & 24.2 & 520 \\
\hline $\operatorname{LSD}(0.05)$ & 0.02 & 0.4 & 0.9 & 1.1 & 0.5 & 3.16 & 1.6 & 2.4 & 458 & 7.96 & 1.1 & 122 \\
\hline 0 & 0.98 & 8.9 & 3.2 & 11.2 & 6.1 & 9.7 & 9.4 & 8.3 & 2700 & 59.5 & 23.4 & 636 \\
\hline 200 & 0.98 & 9.3 & 3.6 & 11.5 & 6.7 & 12.1 & 10.2 & 10.4 & 2669 & 57.4 & 24.3 & 658 \\
\hline 400 & 0.97 & 9.5 & 3.7 & 12.6 & 6.8 & 13.2 & 11.4 & 11.7 & 2680 & 54.4 & 23.6 & 634 \\
\hline 600 & 0.97 & 9.8 & 3.9 & 12.3 & 6.7 & 14.3 & 11.8 & 12.5 & 3403 & 56.2 & 23.9 & 848 \\
\hline 800 & 0.97 & 9.7 & 4.5 & 12.3 & 6.8 & 15.04 & 11.9 & 13.2 & 3268 & 65.1 & 23.9 & 792 \\
\hline $\operatorname{LSD}(0.05)$ & 0.04 & 0.7 & 1.4 & 12.5 & 0.8 & 5.0 & 2.5 & 3.8 & 725 & 12.5 & 1.7 & 194 \\
\hline $\mathrm{S} \times \mathrm{NPK}$ & NS & NS & NS & NS & NS & NS & NS & NS & NS & NS & NS & NS \\
\hline
\end{tabular}

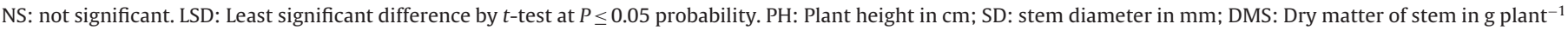

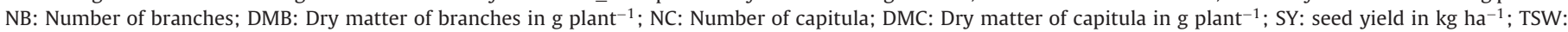
thousand seeds of weight of, g plant ${ }^{-1}$; OIL: Oil content in\%; OY: oil yield in $\mathrm{kg} \mathrm{ha}^{-1}$.

\subsection{Statistical analyses}

Statistical analysis was conducted using a randomised complete block design, with a factorial arrangement. Mean separation was performed by applying the $t$-test at $P \leq 0.05$ level of significance. Fits that provided a coefficient of determination higher than $70 \%$ and minimal significance level of $P \leq 0.05$ were considered satisfactory for the regression models. Regression analysis was performed in Sigma Plot 11.0 software (Jandel Scientific, Sausalito, CA, USA). Linear response plateau was used for seed yield and oil yield, using SAS PROC NLIN (SAS Institute, 2014).

\section{Results and discussion}

Safflower grown in autumn received approximately $1.170 \mathrm{~mm}$ rainfall, which is above the rainfall level in the winter season $(600 \mathrm{~mm}$ ) and also above the amount required throughout the cycle for optimal growth, since safflower requires 800-1000 mm (Oyen and Umali, 2007), especially due to its slow initial growth characterized by the rosette stage. However, according to Oyen and Umali (2007), this crop may also grow in regions of low water availability and dry climate under minimal rainfall requirements (300 $\mathrm{mm}$ ) before reaching the flowering stage. In this sense, the time of sowing is the factor that most affects safflower crops, as a delayed or early sowing could compromise productivity (Mohamadzadeh et al., 2011), leading to reduction of the canopy area and also diseases after flowering.

\subsection{Yield components}

Growth components of the vegetative phase were affected $(P \leq 0.05)$ by fertilization, especially in autumn, except for plant height and stem dry matter (Fig. 2A-F).Janmohammadi et al. (2016) also studied safflower grown in autumn and observed that the application of fertilizers improved growth characteristics. In this study, except for the number of branches, yield components were higher in the autumn season (Table 2). However, there was a difference of $67 \%$ in plant height and $119 \%$ in stem dry matter between both growing seasons.

Similarly, accumulation of dry matter of root, branches and capitula, and also stem diameter benefited from sowing in autumn (Table 2). This is due to low rainfall after sowing, since the growing period is highly important to the safflower crop, because that is the period in which plants are more severely affected by water stress (Hussain et al., 2015). Stem diameter was not sensitive to intermediate fertilizer rates, but it was strongly affected by the rate of $800 \mathrm{~kg}$ of NPK fertilizer ha ${ }^{-1}$ (Fig. 2B). Besides, the low accumulation of dry matter in the winter season is also related to the uptake of nutrients, especially nitrogen, whose absorption, accumulation, partitioning and translocation rates in safflower plants are affected in drought conditions (Dordas and Christos, 2009). Reduction of the root system and relative growth rate was observed in safflower genotypes under water deficit conditions (Hojati et al., 2011). Bellé et al. (2012), in Southern Brazil, observed lower dry matter accumulation when sowing in summer than in the autumn-winter season due to high levels of evapotranspiration. Positive results of autumn sowing have been reported in the literature (Koutroubas et al., 2004; Yau, 2007).

Increasing rates of NPK fertilizer resulted in increased dry matter accumulation during the autumn season, except for stem dry matter (Fig. 2D). Safflower has extensive ramifications and its dry matter accumulation depends not only on plant height and stem diameter (Koutroubas et al., 2004), as observed in this study, but also on branches and leaves, which provide an increase in the number of capitula, which will likely result in higher seed yield. The availability of nutrients, particularly nitrogen, possibly allowed greater accumulation of nutrients, resulting in dry matter accumulation in plant parts during the flowering stage. Dordas and Christos (2009) observed that nitrogen fertilization increased dry matter production in 24\% until anthesis. Anicésio et al. (2015), under controlled conditions, also noted that rates of $\mathrm{N}$ and $\mathrm{P}$ positively influence shoot dry matter. Bonfim-Silva et al. (2015) observed that nitrogen fertilization influenced plant growth in a Cerrado soil under controlled conditions.

The results demonstrate that the uptake of nitrogen by the plant is adapted according to the different rates of fertilizer applied. Safflower has a well-developed root system, so its roots can explore deeper layers of the soil with greater absorption of nutrients, providing enhanced root dry matter results (Dordas and Sioulas, 2008). Hussien and Wuhaib (2010) reported positive results of potassium fertilization rates on root dry matter.

Although the number of branches was not affected by fertilization (Fig. 3A), the NPK rates increased the number of capitula per plant during the autumn season (Fig. 3B). Thus, the number of branches was not responsible for increased production of capitula, once fertilization offset resulted in a greater number of capitula per branch. Dordas and Sioulas (2008) and Abbadi and Gerendas (2011) report that increasing fertilizer rates provided better results concerning to the number of capitula per plant. In this study, the result obtained in the winter season matches that obtained by Lovelli et al. (2007), who reported water stress as responsible for reducing the number of capitula per safflower plant. Studies by Salera (1996) show that late sowing leads to a significant decrease in the number of capitula per plant due to high temperature during the growing season.

For the 1000-seed weight (Fig. 3D), the crop sown in autumn showed an upward exponential trend with the fertilization rate of $800 \mathrm{~kg} \mathrm{NPK} \mathrm{ha}^{-1}$. Safflower 1000 -seed weight showed low sensitivity to low rates of fertilizer in autumn. The weight increase in seeds subjected to fertilizer application can be attributed to the improved 

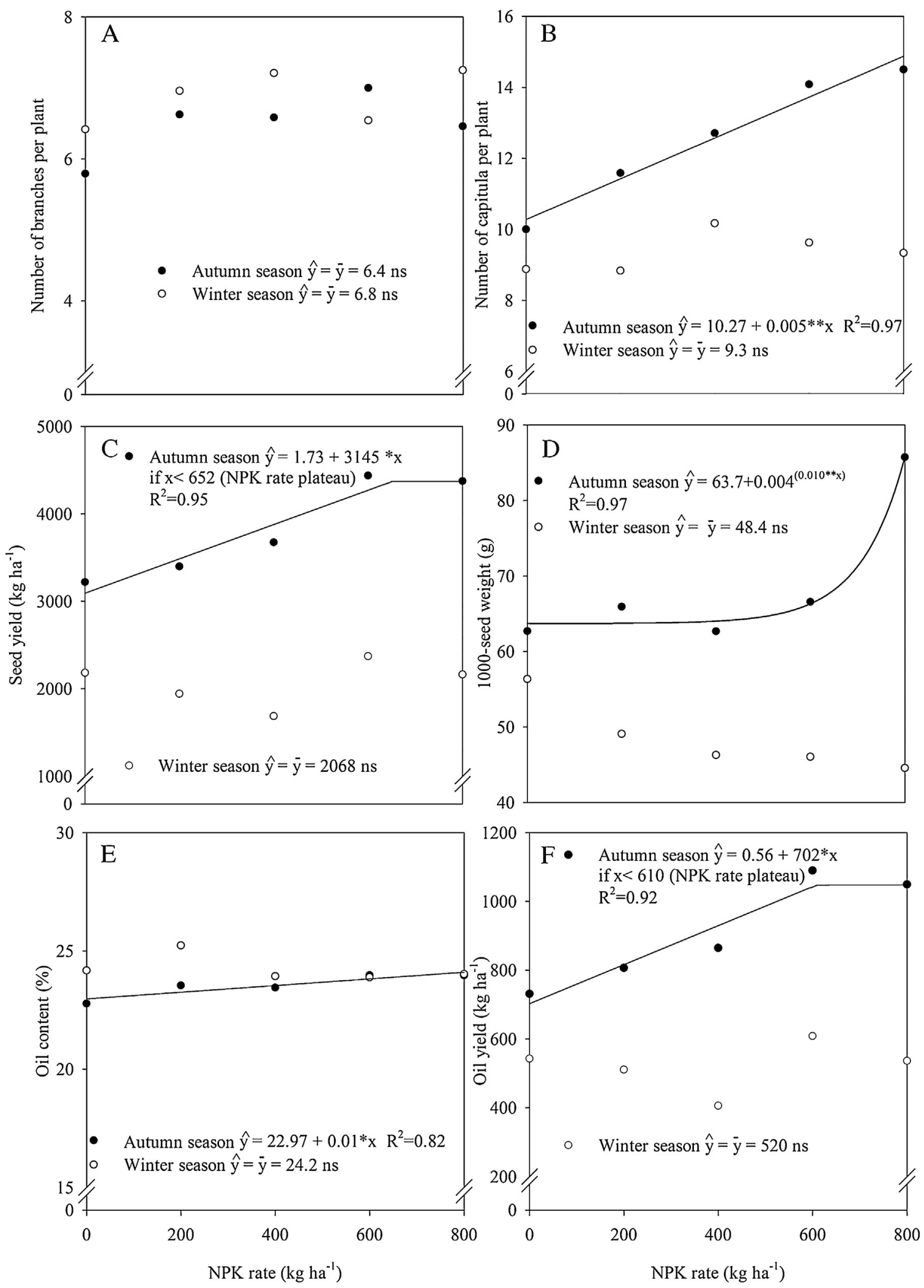

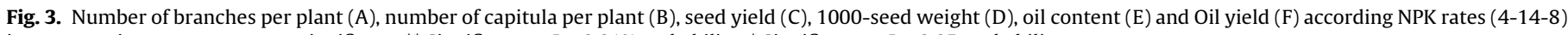
in two growing seasons. ns: not significant. ${ }^{* *}$ Significant at $P \leq 0.01 \%$ probability. ${ }^{*}$ Significant at $P \leq 0.05$ probability.

supply of photo assimilates resulting from the abundance of essential elements, which are utilized for enlargement of the sink cells (Dordas and Sioulas, 2008). According to Koutroubas et al. (2004), the translocation of stored assimilates from vegetative parts to the seeds for seed-filling and seed weight compensation influences the variable, making the correlation with seed yield impossible in some cases. The 1000 -seed weight is also affected by plant characteristics and genes (Brăileanu et al., 2013). Moreover, there was a 41\% dif- 
ference in the 1000-seed weight between the first season (autumn, $68.7 \mathrm{~g}$ ) and the second (winter, $48.5 \mathrm{~g}$ ).

\subsection{Oil content}

In what concerns to oil content (Fig. 3E), which is a determining factor for oilseed crops, basic NPK fertilization caused an increase of $23.9 \%$ in the autumn crop. However, there was only a difference of $0.8 \%$ from the average value of the winter crop (24.1\%), which demonstrates the low variability of this variable, which is due to maximum transfer of assimilates for seed development instead of producing more vegetative parts and seeds, as commonly found in the literature. The analysis of variance (ANOVA) did not detect significant differences between both seasons (Table 2). According to Rathke et al. (2005), optimizing the oil content involves balancing protein synthesis and crude oil levels in the seeds as well as energy and carbon dioxide $\left(\mathrm{CO}_{2}\right)$, because nitrogen-based fertilizers may affect such synthesis.

The values reported in this study are below the 35-45\% range, which is the average content range found in the literature (Kaya et al., 2003; Mahasi et al., 2009). That is due to the genotype used in the study, which presents low oil content. Elfadl et al. (2009) also observed that the obtained oil content in temperate conditions with nitrogen rates was low (22\%), which, according to the authors, is due to the crop used in the study and the environment.

\subsection{Seed yield and oil yield}

Seed yield benefited from the NPK fertilization only in the autumn crop (Fig. 3C), the time in which the use of nutrients was higher, since in the winter crop the contrasting conditions of temperature and precipitation were crucial to productivity reduction. However, the average yield ( $2068 \mathrm{~kg} \mathrm{ha}^{-1}$ ) (Table 2 ) observed in the winter crop is within the $1000-3300 \mathrm{~kg} \mathrm{ha}^{-1}$ range, obtained in the Pampas region of Argentina (Quiroga et al., 2001), in Potenza, Italy (Lovelli et al., 2007) and in Orissa, India (Kar et al., 2007). The linear plateau model predicted an increasing relative yield with NPK rates $<652 \mathrm{~kg} \mathrm{NPK} \mathrm{ha}^{-1}$, resulting in relative seed yield of approximately $4374 \mathrm{~kg} \mathrm{ha}^{-1}$. The result of this study also agrees with the results reported by Ghanbari-Odivi et al. (2013), in which safflower showed higher productivity with sowing in May (autumn) than in July (winter). Early sowing combined with favorable conditions and a long growing season results in increased seed development and yield (Adisarwanto and Knight, 1997). Positive results on autumn sowing have been reported in the literature (Koutroubas et al., 2004; Yau, 2007). Contrasting climate conditions and the lower concentrations of $\mathrm{P}$ and $\mathrm{K}$ in the winter season caused the NPK fertilization to be inefficient.

Oil yield is a combination of seed yield and oil content, so it was highly influenced by seed yield $(r=0.98 ; p<0.0001)$ (Fig. 2E). The linear plateau model predicted an increasing relative yield with NPK rates $<610 \mathrm{NPK} \mathrm{ha}^{-1}$, resulting in relative oil yield of approximately $1048 \mathrm{~kg} \mathrm{ha}^{-1}$. Even having lower oil content than that reported in the literature, the high seed yield observed in the autumn crop was responsible for an efficient oil yield in this study.

Safflower flowering in the winter season occurred under good rainfall conditions (Fig. 1), however, the water deficit during the plant development stages limited productivity, as also noted by Istanbulluoglu et al. (2009). Singh et al. (2016), in the southern plains in New Mexico, USA, observed a productivity decrease above $70 \%$ in safflower cultivated under irrigated conditions in comparison to that cultivated in a dry farming system.

The plateau model indicated that a fertilizer rate slightly higher than $600 \mathrm{~kg}$ NPK ha ${ }^{-1}$ would be sufficient for safflower seed yield and oil yield, with $24 \mathrm{~kg} \mathrm{Nha}^{-1}, 108 \mathrm{~kg} \mathrm{P}_{2} \mathrm{O}_{5} \mathrm{ha}^{-1}$ and $48 \mathrm{~kg} \mathrm{~K}_{2} \mathrm{O} \mathrm{ha}^{-1}$. A lower amount of $\mathrm{N}\left(24 \mathrm{~kg} \mathrm{ha}^{-1}\right)$ was enough for achieving satisfactory yield. Nitrogen is one of the most important nutrients for crop production. Growth is reduced when nitrogen level in the soil is not optimal. In the past, fertilizers using $20-50 \mathrm{~kg} \mathrm{~N} \mathrm{ha}^{-1}$ were described as appropriate for semi-arid rainfed agriculture in California (Knowles and Miller, 1960). Yau and Ryan (2010) carried out a multi-year study in the Mediterranean environment in which safflower did not respond to $\mathrm{N}$ application in a no-tillage system. Dordas and Sioulas (2008) applied nitrogen fertilizer rates of 100 and $200 \mathrm{~kg} \mathrm{ha}^{-1}$ and obtained increased safflower seed yield even though their soil $\mathrm{NO}_{3}$ levels were higher. The discrepancy found in the nitrogen fertilizer requirement for the safflower crop may be related to the soil management system in which the crop is managed, different genotypes, preceding crop, residual nitrogen content in the soil and climatic conditions.

It is assumed that the results are related to the ability of the safflower crop and to the soil with high concentrations of P and K. In the winter season, water stress in the early stages may have reduced nutrient uptake by the roots and translocation in the plant due to the low perspiration rate, which decreased active transport and impaired membrane permeability (Hu and Schmidhalter, 1998), causing contrasting results of seed yield and oil yield between autumn and winter seasons.

\section{Conclusions}

Safflower seems promising as an alternative oilseed crop for Southern Brazil when sown in autumn with basic fertilizer. Even in a Rhodic Acrudox with high concentrations of $P$ and $K$, the linear plateau model predicted an increasing relative yield with NPK rates $<652 \mathrm{~kg}$ and $<610 \mathrm{NPK} \mathrm{ha}^{-1}$ resulting in relative seed yield and oil yield of approximately $4374 \mathrm{~kg} \mathrm{ha}^{-1}$ and $1048 \mathrm{~kg} \mathrm{ha}^{-1}$, respectively.

\section{References}

Abbadi, J., Gerendas, J., 2011. Effects of phosphorus supply on growth, yield and yield components of safflower and sunflower. J. Plant Nutr. 34, 1769-1787.

Abbasieh, S.K., Shirani, R.A.D., Delkhosh, A.H., 2013. Mohamadi, Effect of different potassium levels and different humidity conditions: in the use of zeolite and disuse zeolite in safflower. Ann. Biol. Res. 8, 56-60.

Adisarwanto, A., Knight, R., 1997. Effect of sowing date and plant density on yield and yield components in the faba bean. Aust. J. Agric. Res. 48, 116-118.

Anicésio, E.C.A., Bonfim-Silva, E.M., da Silva, T.J.A., Koetz, M., 2015. Dry mass: nutrient concentration and accumulation in safflower (Carthamus tinctorius L.) influenced by nitrogen and potassium fertilizations. Aust. J. Crop Sci. 9, $552-560$.

Bellé, R.A., Rocha, E.K., Backes, F.A.A.L., Neuhaus, M., Schwab, N.T., 2012. Safflower grown in different sowing dates and plant densities. Cien. Rural 42, 2145-2152.

Bicudo, S.J., Cruz, S.C.S., Pereira, F.R.S., Brachtvogel, E.L., Madalena, J.A.S., 2009. Níveis de adubação para a cultura do milho safrinha. Caatinga 22, 23-30.

Bonfim-Silva, E., Paludo, J.T.S., Sousa, J.V.R., Sousa, H.H.F., Silva, T.J.R., 2015. Development of safflower subjected to nitrogen rates in cerrado soil. Am. J. Plant Sci. 6, 2136-2143.

Brăileanu, S.I., Kadar, R.R., Duda, M.M., Gocan, T.M., Moldovan, C., 2013. The influence of technological elements on some production components for the spring wheat. ProEnvironment 6, 379-383.

Brasil, 2009. Ministério da Agricultura, Pecuária e Abastecimento. Regras para análise de sementes/Ministério da Agricultura, Pecuária e Abastecimento. Secretaria de Defesa Agropecuária, Brasília.

Colnago, L.A., Azeredo, R.B.V., Marchi Netto, A., Andrade, F.D., Venâncio, T., 2011 Rapid analyses of oil and fat content in agri-food products using continuous wave free precession time domain NMR. Magn. Reson. Chem. 49, 113-120.

Cosge, B., Gurbuz, B., Kiralan, M., 2007. Oil content and fatty acid composition of some safflower (Carthamus tinctorius L.) varieties sown in spring and winter. Int. J. Nat. Eng. Sci. 1, 11-15

Dordas, C.A., Christos, S., 2009. Dry matter and nitrogen accumulation partitioning, and retranslocation in safflower (Carthamus tinctorius L.) as affected by nitrogen fertilization. Field Crop Res. 110, 35-43.

Dordas, C.H., Sioulas, C.H., 2008. Safflower yield, chlorophyll content, photosynthesis and water use efficiency response to nitrogen fertilization under rainfed conditions. Ind. Crops Prod. 27, 78-85.

El-Mohsen, A.A.A., Mahmoud, G.O., 2013. Modeling the influence of nitrogen rate and plant density on seed yield: yield components and seed quality of safflower. Am. J. Exp. Agric. 3, 336-360. 
Elfadl, E., Reinbrecht, C., Frick, C., Claupein, W., 2009. Optimization of nitrogen rate and seed density for safflower (Carthamus tinctorius L.) production under low-input farming conditions in temperate climate. Field Crop Res 114, 2-13.

Ghanbari-Odivi, A., Hashemzade, H., Bahrampour, B., Saeidi, M., 2013. Effect of sowing date on yield and its components, oil and protein concentration and some agronomical traits of safflower (Carthamus tinctorius L.). Tec. J. Eng. Ap. Sc. 3, 1405-1410.

Golzarfar, M., Shirani Rad, A.H., Delkhosh, B., Bitarafan, Z., 2012. Safflower (Carthamus tinctorius L.) response to different nitrogen and phosphorus fertilizer rates in two planting seasons. Zemdirbyste-Agric. 99, 159-166.

Haghighati, A., 2010. Study on the effect of nitrogen and phosphorus fertilizers on the yield and oil content of safflower lines in drylands. Res. J. Agron. 4, 357-362.

Hojati, M., Modarres-Sanavy, S.A.M., Karimi, M., Ghanati, F., 2011. Responses of growth and antioxidant systems in Carthamus tinctorius L. under water déficit stress. Acta Physiol. Plant 33, 105-112.

Hu, Y., Schmidhalter, U., 1998. Spatial distributions and net deposition rates of mineral elements in the elongating wheat (Triticum aestivum L.) leaf under saline soil conditions. Planta 204, 212-219.

Hussain, M.I., Dionyssia-Angeliki, L., Farooq, M., Nikoloudakis, N., Khalid, N., 2015. Salt and drought stresses in safflower: a review. Agron. Sustain. Dev. 36, 1-31.

Hussien, L.A., wuhaib, K.M., 2010. The relationship between root growth and yield in safflower influenced by irrigation interval and potassium levels. Iraqi J. Agric. Sci. 41, 30-45.

Istanbulluoglu, A., Gocmen, E., Gezer, E., Pasa, C., Konukcu, F., 2009. Effects of water stress at different development stages on yield and water productivity of winter and summer safflower (Carthamus tinctorius L.). Agric. Water Manage. 96, 1429-1434.

Janmohammadi, M., Amanzadeh, T., Sabaghnia, N., Ion, V., 2016. Effect of nano-silicon foliar application on safflower growth under organic and inorganic fertilizer regimes. Bot. Lith. 22, 53-64.

Kar, G., Kumar, A., Martha, M., 2007. Water use efficiency and crop coefficients of dry season oilseed crops. Agric. Water Manage. 87, 73-82.

Kaya, M.D., Ipek, A., Oztork, A., 2003. Effects of different soil salinity levels on germination and seedling growth of safflower (Carthamus tinctorius L.). Turk. J. Agric. For. 27, 221-227.

Knowles, P.F., Miller, M.D., 1960. Safflower in california. In: California Agricultural Experiment Station and Extension Service, Manual 27. University of California, Davis.

Koutroubas, S.D., Papakosta, D.K., Doitsinis, A., 2004. Cultivar and seasonal effects on the contribution of pre-anthesis assimilates to safflower yield. Field Crop Res. 90, 263-274.

Lovelli, S., Perniola, M., Ferrara, A., Di Tommaso, T., 2007. Yield response factor to water (Ky) and water use efficiency of Carthamus tinctorius L. and Solanum melongena L. Agric.Water Manage. 92, 73-80.

Mündel, H.H., 2004. Safflower Production on the Canadian Prairies: Revisited in 2004. Lethbridge Research Station, Agriculture and Agri-Food Canada, Lethbridge, Altanta.
Mahasi, M., Wachira, F., Pathak, R., Riungu, T., 2009. Genetic polymorphism in exotic safflower (Carthamus tinctorious L.) using RAPD markers. J. Plant Breed. Crop Sci. 1, 8-12.

Merrill, S.D., Tanaka, D.L., Hanson, J.D., 2002. Root length growth of eight crop species in Haplustoll soils. Soil Sci. Soc. Am. J. 66, 913-923.

Mohamadzadeh, M., Seyed, S.A., Norof, M.S., Naseri, R., 2011. The effects of planting date and row spacing on yield: yield components and associated traits in winter safflower under rain fed conditions. Am. Eurasian J. Agric. Environ Sci. 10, 200-206.

Oyen, L.P.A., Umali, B.E., 2007. Carthamus tinctorius L. record from protabase. In: van der Vossen, H.A.M., Mkamilo, G.S. (Eds.), PROTA (Plant Resources of Tropical Africa/Ressources végétales De l'Afrique Tropicale). Wageningen, Netherlands.

Palizdar, M., Delkhosh, B., Rad, A.H.S., 2011. Effect of irrigation regimes on agronomic traits of safflower (Carthamus tinctorius L.) under different levels of K fertilization. J. Plant Ecophysiol. 3, 15-21.

Quiroga, A.R., Díaz-Zorita, M., Buschiazzo, D.E., 2001. Safflower productivity as related to soil water storage and management practices in semiarid regions. Commun Soil Sci. Plant Anal. 32, 2851-2862.

Rathke, G.W., Christen, O., Diepenbrock, W., 2005. Effects of nitrogen source and rate on productivity and quality of winter oilseed rape (Brassica napus L.) grown in different crop rotations. Field Crops Res. 94, 103-113.

Institute, S.A.S., 2014. SAS User's Guide: Statistics. SAS Inst., Cary, NC.

Salera, E., 1996. Yield and quality of safflower (Carthamus tinctorius L.) grown at different plant populations and row spacing. Agric. Medeterranea 126, 354-363.

Santos, R.F., Silva, M.A., 2015. Carthamus tinctorius L.: Uma alternativa de cultivo para o Brasil. Acta Iguazu 4, 26-35.

Santos, R.F., Silva, M.A., Klar, A.E., Zanotto, M.D., Bassegio, D., 2015. Comportamento morfológico no período de crescimento de genótipos de Carthamus tinctorius L. em cultivo sob sequeiro e irrigado. Revista Brasileira de Energias Renováveis 4, 146-167.

Senkal, B.C., Kiralan, M., Ramadan, M.F., 2016. Impact of harvest times on the quality characteristics of oils recovered from different safflower (Carthamus tinctorius) cultivars sown in spring and autumn. Eur. Food Res. Technol. 242, $371-381$.

Sherrard, M.E., Maherali, H., 2006. The adaptive significance of drought escape in Avena barbata, an annual grass. Evolution 60, 2478-2489.

Singh, S., Angadi, S.V., Grover, K., Begna, S., Auld, D., 2016. Drought response and yield formation of spring safflower under different water regimes in the semiarid Southern High Plains. Agric. Water Manage. 163, 354-362.

Soil Survey Staff, 2014. Keys to Soil Taxonomy, 12th ed. USDA-Natural Resources Conservation Service, Washington, DC

Yau, S.K., Ryan, J., 2010. Response oh rainfed safflower to nitrogen fertilization under Mediterranean conditions. Ind. Crop. Prod. 32, 318-323.

Yau, S.K., 2007. Winter versus spring sowing of rain-fed safflower in a semi-arid, high-elevation Mediterranean environment. Eur. J. Agron. 26, 249-256. 